\title{
Synthesis, Spectroscopic Characterization and Biological Applications of Novel Zinc Complexes with Schiff Bases
}

\author{
MEHRINE Rehman ${ }^{1, a,}$, SAQIB Ali ${ }^{2}$, KHURRAM Shahzad Munawar ${ }^{2}$ \\ ${ }^{1}$ Centres of Science and Applied Technologies (CESAT), Islamabad, Pakistan \\ ${ }^{2}$ Department of Chemistry, Quaid-i-Azam University, Islamabad, 45320, Pakistan \\ ${ }^{a}$ rmehrine@gmail.com
}

\begin{abstract}
Keywords: Schiff Base, Diabetes Mellitus, Anticancer, Antitumor, DNA Binding Activity, UV Spectroscopy, Antibacterial, Antifungal, Disc Diffusion Method.
\end{abstract}

\begin{abstract}
Schiff base ligands, having nitrogen and oxygen donor sites and their zinc(II) complexes have been prepared by using methanol as a solvent. Purity of the compounds were tested by TLC and characterized by FT-IR, multinuclear NMR $\left({ }^{1} \mathrm{H}\right.$ and $\left.{ }^{13} \mathrm{C}\right)$. FT-IR spectra suggested the binding of precursors and their chelation with zinc(II) moieties by showing characteristics peaks in particular regions. ${ }^{1} \mathrm{H}-\mathrm{NMR}$ also approves the synthesis of compounds by showing characteristics peaks of azomethine proton $(\mathrm{HC}=\mathrm{N})$ and phenolic proton $(-\mathrm{OH})$. On complexation phenolic proton was disappeared while a down field shift was observed in azomethine proton. ${ }^{13} \mathrm{C}-\mathrm{NMR}$ data further supported the formation of compounds by displaying and shifting of characteristic peaks of azomethine carbon $(\mathrm{HC}=\mathrm{N})$. The DNA binding ability of all the synthesized ligands was studied by UV-Visible spectroscopy. A hypochromic affect was observed showing that ligands interacted with DNA by intercalation. The results implied that these synthesized compounds can be employed for the formulation of Anticancer and Antitumor drugs in future with less toxic side effects to normal cells (unlike toxic drugs presently used). Moreover they were found to have antifungal and antibacterial activity by Disc Diffusion method. Zinc containing complexes had been investigated a lot recently for the treatment of Diabetes Mellitus. Thus, these synthesized compounds are potential drug candidates for research if explored.
\end{abstract}

\section{Introduction}

Many of the diseases had been treated in ancient ages by using variety of metal comprising inorganic compounds. The advancement in medicinal usage of inorganic compounds started in early twenties for the cure of diseases.

Table 1 Established and potent zinc pharmaceutics

\begin{tabular}{cccc}
\hline Element & Year & Treatment & Compound \\
\hline \multirow{3}{*}{$\mathrm{Zn}$} & 2002 & Stomach ulcer, Diabetes mellitus & Zinc complexes \\
& 2003 & UV-induced dermatitis & Zinc complexes \\
& 2007 & Metabolic syndrome \& Diabetes & $\begin{array}{c}\text { Zinc-thioalloxan- } N \text {-methyl } \\
\text { Zinc-dithiocarbamate }\end{array}$ \\
& 2008 & Wilson disease & Zinc-acetate \\
\hline
\end{tabular}

Deficiency of zinc in kids is responsible for stunt growth, delay of sexual maturity, weakening of immune system, diarrhea and many further related diseases that lead to increase mortality rate in infants especially in developing countries [1]. There are many biological applications of zinc like it is necessary for development and growth. Presently, antidiabetic activities of zinc are very significant. Zinc and diabetes mellitus (DM) are related at many steps in the process of metabolism within a cell [2]. 


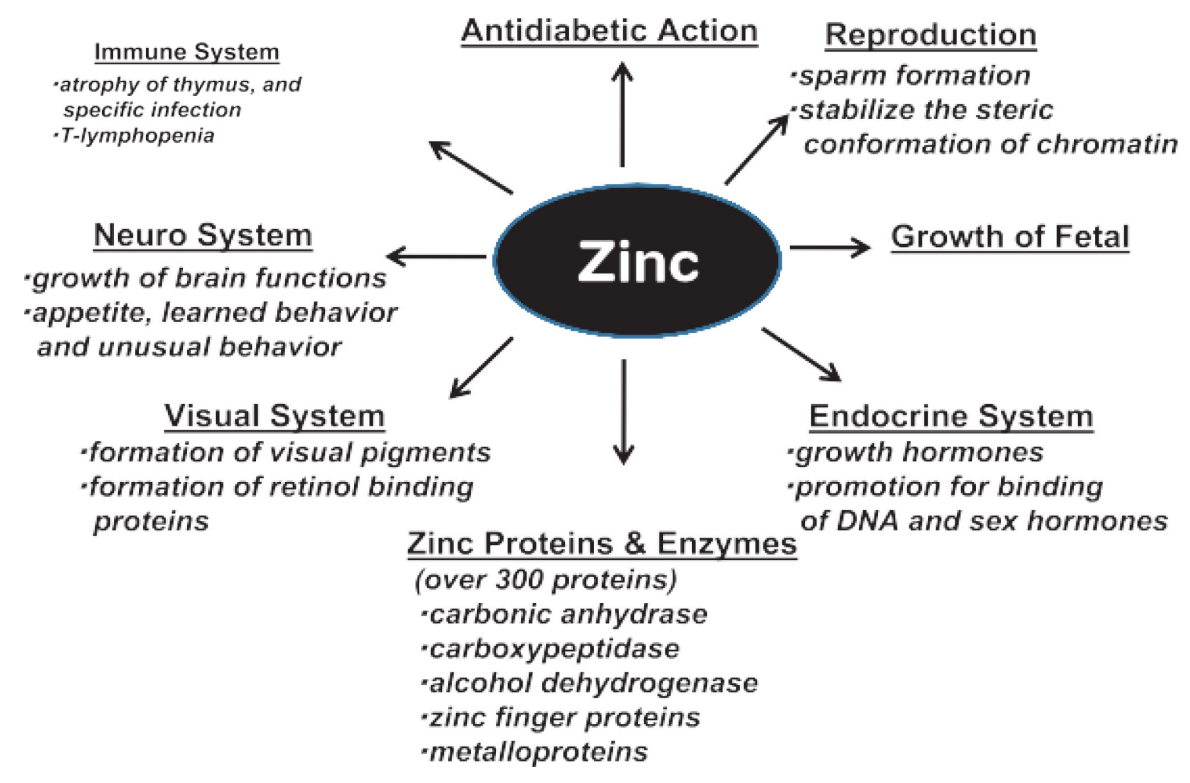

Fig. 1 Biological uses of zinc

In 1992, it was found that it controls blood glucose level as that of insulin by regulating rat adipocytes lipogenesis followed by in-vivo observation of insulin mimetic effects of orally administrated zinc chloride in Streptozotocin-induced type (STZ) diabetic rats and mice [3]. One of the major drawbacks of $\mathrm{ZnCl}_{2}$ was its low bioavailability, so sufficiently high amount of dose or treatment for the long time (more than 8 weeks) is required. That's why in order to avoid these problems the zinc metal complexes were suggested. In 2002, first orally active antidiabetic zinc complex was discovered. Since then, an extensive range of insulin mimetic zinc complexes having diverse coordination sites around zinc has been suggested [4].

Zinc stimulates lipogenesis and transport of glucose transport in adipocyte tissues; its administration via diet decreases high blood sugar level in artificially diabetic mice. Medical investigations also disclosed that there is a connection amongst deficiency of zinc and diabetes mellitus [5]. Few years back, in animals with outstanding antidiabetic and anti-metabolic syndrome properties of the zinc containing complexes have been investigated as the compounds have excellent hypoglycemic abilities on oral administration [6]. Investigations on zinc as a model role in the treatment of diabetes mellitus have been conducted on the diabetic models of animals. The investigations revealed that increased ingestion of zinc containing food remarkably decreased the harshness of type 1 diabetes mellitus.

Normally Schiff bases are generally synthesized by the condensation reactions of carbonyls and amines under different conditions and by using variety of solvents with the elimination of water molecules. The excellent chelation ability of Schiff bases along other properties like easy synthesis and flexibility in changing the chemical surroundings to azomethine specie $(\mathrm{HC}=\mathrm{N})$. Generally, transition metal complexes of Schiff bases are synthesized by reacting them with salts of metals.

DNA is genetic material for all higher organisms.

The basic components of DNA are.

- Deoxyribose sugar having five carbon atoms in the form of cyclic ring

- Phosphate group

- Nitrogenous bases, adenine (A), guanine $(\mathrm{G})$, cytosine $(\mathrm{C})$ and thymine $(\mathrm{T})$

A double hydrogen bond is developed between $\mathrm{A}$ and $\mathrm{T}$, while $\mathrm{G}$ and $\mathrm{C}$ makes a triple hydrogen bond $[7,8]$. DNA is the specific point of action of almost all anticancer/antitumor drugs in order to regulate the uncontrolled cell division. These anti-tumor drugs make anadduct with DNA by blocking the particular active sites of DNA which are responsible for replication and elongation of chain. DNA can interact covalently to metal center through oxygen atom of sugar phosphate backbone or to the nitrogen atom of nitrogenous bases, or non-covalently through intercalation or hydrogen bonding. The metal complexes or drugs that interact with DNA can inhibit the processes 
related to DNA, such as replication and transcription by forming drug DNA adducts or by distortions of DNA structure leading to apoptosis or cell death.

\section{Experimental}

The chemicals used in the present study are of analytical grade and used without additional purification. Zinc salt e.g. $\mathrm{Zn}\left(\mathrm{CH}_{3} \mathrm{COO}\right)_{2} \cdot 2 \mathrm{H}_{2} \mathrm{O}$ was purchased from Sigma Aldrich and the precursors for the synthesis of ligands were of Acros organics.

Solvents were purified where needed, before use according to the standard procedure [9]. Gallenkamp (Japan) was used to find out the melting point of synthesized compounds with the help of capillary tubes. Infra-red spectral studies, in the range of 4000 to $250 \mathrm{~cm}^{-1}$ were carried out on a Nicolet-6700 FT-IR spectrophotometer; Proton and Carbon-13 NMR spectra in deuterated solvents. The electronic absorption spectra were taken on a Shimadzu 1800 UV-Visible Spectrophotometer.

Ligands were synthesized by refluxing stoichiometric amounts of 2-hydroxy-1-naphthaldehyde, an aldehyde with p-toluidine $\left(\mathrm{HL}^{1}\right)$ and 2-aminophenol $\left(\mathrm{HL}^{2}\right)$ separately in absolute ethanol for 34 hours.<smiles>[X]c1cc(I)ccc1N=Cc1c(O)ccc2ccccc12</smiles>

where; $\mathrm{X}=\mathrm{H}, \mathrm{Y}=\mathrm{CH}_{3}$ for $\mathrm{HL}^{1}$ and $\mathrm{X}=\mathrm{OH}, \mathrm{Y}=\mathrm{H}$ for $\mathrm{HL}^{2}$

Generalized chemical procedure for the synthesis of ligands $\mathrm{HL}^{\mathbf{1}}$ and $\mathrm{HL}^{\mathbf{2}}$. Schiff bases, $\mathrm{HL}^{3}$ and $\mathrm{HL}^{4}$ were prepared by the condensation of equimolar (1:1) amounts of 5-chloro-2hydroxybenzaldehyde with 2-aminophenol $\left(\mathrm{HL}^{3}\right)$ and ethyl 4-aminobenzoate $\left(\mathrm{HL}^{4}\right)$, separately, in absolute ethanol $(100 \mathrm{~mL})$. Completion of the reaction was monitored by TLC. The crystalline products were separated by filtration, purified by washing with absolute ethanol and finally dried under vacuum. Zinc(II) complexes $1-4$ were synthesized by mixing $\mathrm{Zn}\left(\mathrm{CH}_{3} \mathrm{COO}\right)_{2} \cdot 2 \mathrm{H}_{2} \mathrm{O}$ with $\mathrm{HL}^{1}$ and $\mathrm{HL}^{4}$ in $1: 2$ ratio and $\mathrm{HL}^{2}$ and $\mathrm{HL}^{3}$ with $1: 1$, using ethanol $(100 \mathrm{ml})$ as a solvent.

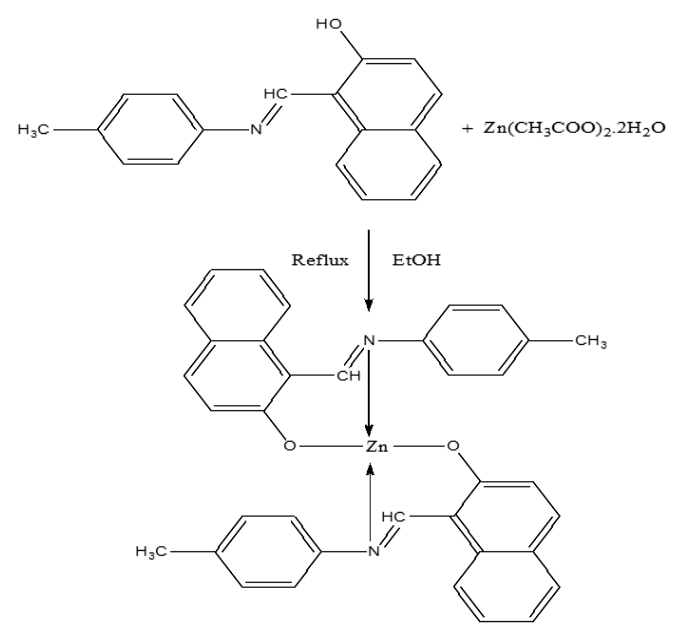


Generalized chemical procedure for the synthesis of zinc(II) complex (1).

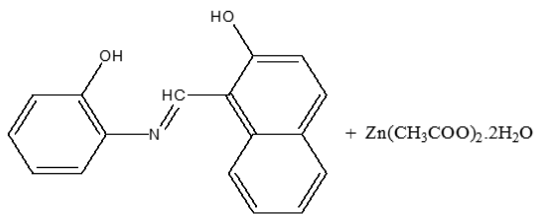<smiles>c1ccc2c(c1)Oc1ccccc1[Te]1Oc3ccccc3N21</smiles>

Generalized chemical procedure for the synthesis of zinc(II) complex (2).

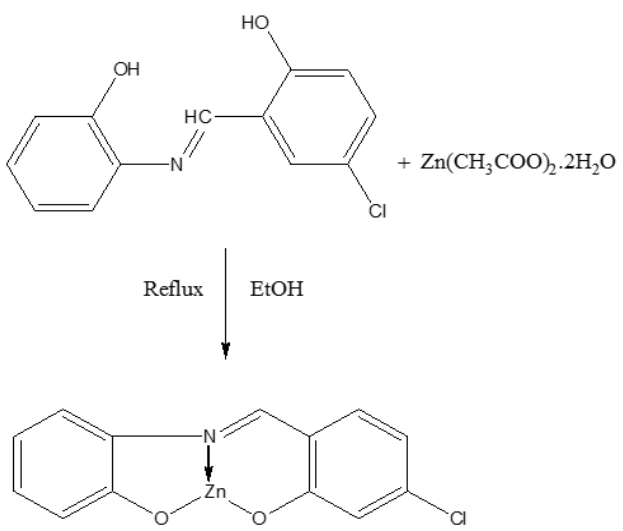

\section{Generalized chemical procedure for the synthesis of zinc (II) complex (3).}

Salmon sperm DNA (SS-DNA) (20 mg) was dissolved in doubly deionized water at neutral $\mathrm{pH}$, kept at $4^{\circ} \mathrm{C}$ and used within 4 days. In order to check whether protein is attached with DNA or not, absorbance of DNA at 260 and $280 \mathrm{~nm}$ was measured, the ratio 1.9:1 showed that DNA is free of protein [10]. For UV absorption studies $10 \mathrm{~mL}$ solution of SS-DNA and compound was prepared. In a sample cuvette concentration of SS-DNA was increased after each measurement while the concentration of compound was fixed, with a reference solution without the compound. The data was then placed into the following Benesi-Hildebrand equation [11], to get the value of intrinsic binding constant, $\mathrm{K}$ :

$$
\frac{A_{\circ}}{A-A_{\circ}}=\frac{\varepsilon_{G}}{\varepsilon_{H-G}-\varepsilon_{G}}+\frac{\varepsilon_{G}}{\varepsilon_{H-G}-\varepsilon_{G}} \times \frac{1}{K[D N A]}
$$

where

$$
\begin{aligned}
& \mathrm{K}=\text { Binding constant } \\
& \mathrm{A}_{\mathrm{O}}=\text { Absorbance of the drug } \\
& \mathrm{A}=\text { Absorbance of the drug-SS-DNA adduct } \\
& \varepsilon_{\mathrm{G}}=\text { Absorption coefficient of the drug } \\
& \varepsilon_{\mathrm{H}-\mathrm{G}}=\text { Absorption coefficient of the drug-SS-DNA adduct }
\end{aligned}
$$

The binding constants [K] (affinity the drug/complex with DNA) may be calculated from the intercept-to-slope ratios of $\mathrm{A}_{\mathrm{o}} /\left(\mathrm{A}-\mathrm{A}_{\mathrm{o}}\right)$ vs. $1 /[\mathrm{DNA}]$ plots.

The fungicidal and bactericidal activities of the synthesized compounds against various bacteria and fungi were carried out. The bacterial strains (Escherichia coli, Bacillus subtilis, Staphlocuccus aureus and Pasturella multocida) were cultured overnight at $37^{\circ} \mathrm{C}$ in nutrient agar. 
The pure bacterial cultures obtained were maintained in the medium in slants and petri plates. For inoculums preparation, $13 \mathrm{~g}$ of nutrient broth was suspended in one liter of distilled water, homogenously mixed and autoclaved for 15 minutes at $121^{\circ} \mathrm{C}$. Then $10 \mu \mathrm{L}$ of pure culture of a bacterial strain was added to $100 \mathrm{~mL}$ of freshly prepared nutrient broth medium. The fungal strains (Alternaria alternata, Ganoderma lucidum, Aspergillus nigerand Penicillium notatum) were cultured overnight at $28^{\circ} \mathrm{C}$ using potato dextrose agar.Antimicrobial activities were measured by using disc diffusion method [12] . $2.8 \mathrm{~g}$ nutrient agar (for antibacterial activities) or $3.9 \mathrm{~g}$ potato dextrose agar (for antifungal activities) was suspended in $100 \mathrm{~mL}$ distilled water and sterilized by autoclaving at $121^{\circ} \mathrm{C}$ for 15 minutes. It was then mixed well with $100 \mu \mathrm{L}$ inoculums and was poured in sterilized petri plates. Clear zones of inhibition formed around the discs were measured in millimeters using a zone reader [13]. The zone inhibition was calculated by using the following equation.

$$
\% \text { Growth inhibition }=100-\left(\frac{\text { Linear growth in test sample }(\mathrm{mm})}{\text { Linear growth in control }(\mathrm{mm})} \times 100\right)
$$

\section{Results and Discussions}

Schiff base ligands and their zinc complexes are synthesized in excellent yield. All the synthesized products are in solid state, having sharp melting points. The synthesized products have been characterized by FT-IR and multinuclear NMR $\left({ }^{1} \mathrm{H}\right.$ and $\left.{ }^{13} \mathrm{C}\right)$ spectroscopy.

The FT-IR bands of complexes were assigned by comparing with the free ligand data and their zinc complexes. All the synthesized ligands have two donor sites which are (i) phenolic oxygen $(\mathrm{OH})$ and (ii) azomethine nitrogen $(\mathrm{HC}=\mathrm{N})$. Azomethine group of all the Schiff base ligands gives a strong and sharp peak around $1615-1595 \mathrm{~cm}^{-1}$, which is shifted to lower value around 1613$1580 \mathrm{~cm}^{-1}$ in the complexes advocates its coordination to the metal center. The typical phenolic $v(\mathrm{OH})$ peak for all ligands was observed at $3443-3455 \mathrm{~cm}^{-1}$ is wiped out on complexation presenting the attachment of phenolic oxygen with metal ion. This chelation is further reinforced by the entrance of new peaks at 533-545 $\mathrm{cm}^{-1}$ in complexes due to $v(\mathrm{Zn}-\mathrm{O})$ [ 14].

In the ${ }^{1} \mathrm{H}-\mathrm{NMR}$ spectra of Schiff base ligands and complexes phenolic protons (-OH) usually appear very down field because of hydrogen bonding and are vanished upon complexation. The signals of azomethine protons are shifted down field giving clear indication/evidence of complex formation. ${ }^{13} \mathrm{C}-\mathrm{NMR}$ spectral data of the ligands and complexes were recorded in deuterated solvents. The signals of the azomethine carbon $(\mathrm{HC}=\mathrm{N})$ in the ligands are observed at 178.1-1 $60.4 \mathrm{ppm}$, which after complexation with zinc are shifted down field. Another significant downfield shift upon complexation was observed for the phenolic carbon for complexes of ligand . These peaks shift are good evidence for complexation of ligand with metal atom.

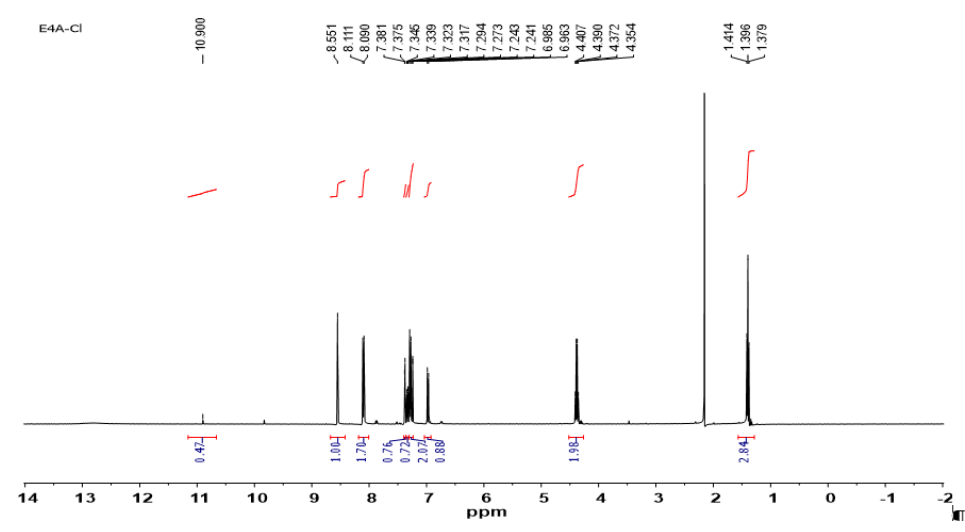

Fig. $2{ }^{1} \mathrm{H}-\mathrm{NMR}$ spectrum of $\mathrm{HL}^{4}$ 
The interaction of synthesized ligands $\mathrm{HL}^{2}-\mathrm{HL}^{4}$ with SS-DNA has been investigated by UVVisible spectroscopy by monitoring the changes in absorption properties of DNA or drug molecules. The UV-Visible titrations of ligands in absence and in presence of SS-DNA have been studied. Negative values of $\Delta \mathrm{G}$ showed the spontaneity of the interaction of the drug with DNA.

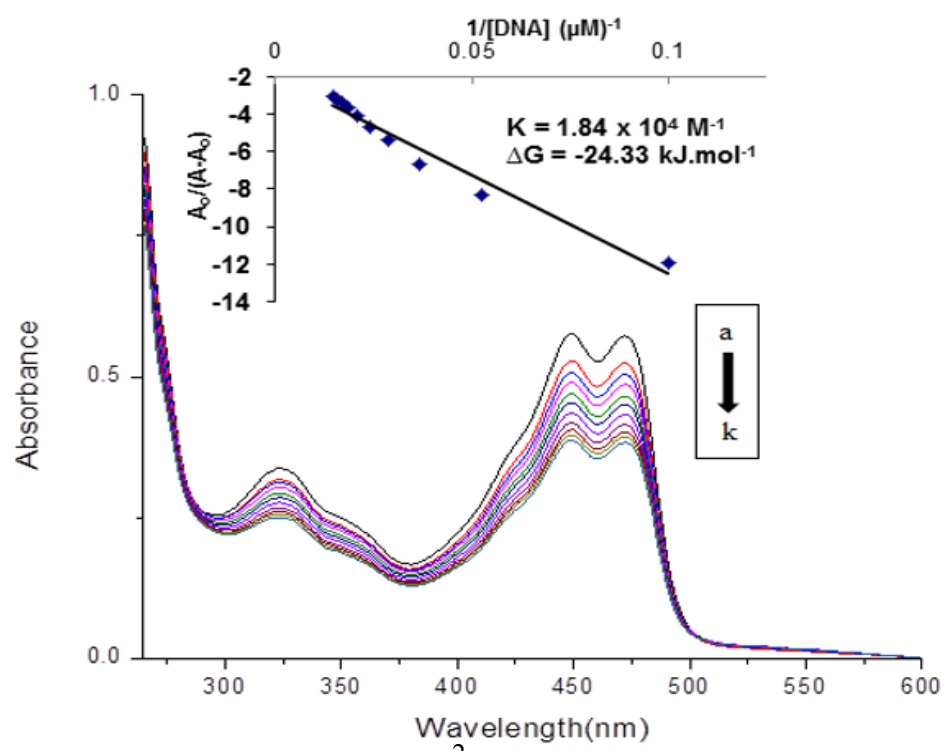

Fig. 3 Absorption spectra of the compounds $\mathrm{HL}^{2}$ in the absence (a) and presence of $10 \mu \mathrm{M}(\mathrm{b})$, $19 \mu \mathrm{M}$ (c), $27 \mu \mathrm{M}$ (d), $35 \mu \mathrm{M}$ (e), $42 \mu \mathrm{M}$ (f), $48 \mu \mathrm{M}$ (g), $54 \mu \mathrm{M}$ (h) $59 \mu \mathrm{M}$ (i), $64 \mu \mathrm{M}$ (j) and $69 \mu \mathrm{M}(\mathrm{k})$ of DNA

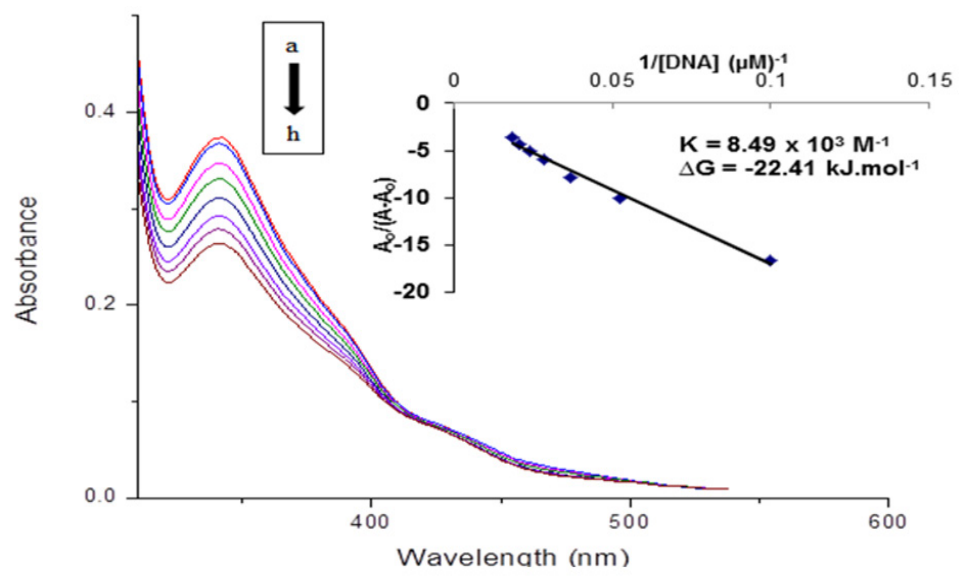

Fig. 4 Absorption spectra of the compounds $\mathrm{HL}^{3}$ in the absence (a) and presence of $10 \mu \mathrm{M}(\mathrm{b})$, $19 \mu \mathrm{M}$ (c), $27 \mu \mathrm{M}$ (d), $35 \mu \mathrm{M}$ (e), $42 \mu \mathrm{M}$ (f), $48 \mu \mathrm{M}$ (g) and $54 \mu \mathrm{M}$ (h) of DNA

Thus, these synthesized compounds interact with DNA leading to improper functioning and cleavage of the DNA double helix structure. The binding constant values are in the range of $5.38 \times$ $10^{3}$ to $18.4 \times 10^{3} \mathrm{M}^{-1}$. The negative values of $\Delta \mathrm{G}$ showed the spontaneity of complex-DNA binding. The moderate binding implies less toxic side effects to normal cells and consequently these synthesized compounds can be employed for the formulation of Anticancer \& Antitumour drugs with less toxic side effects in future.

The synthesized ligands $\mathrm{HL}^{2}-\mathrm{HL}^{4}$ were screened to investigate their in vitro behavior against strains of bacteria (Escherichia coli, Bacillus subtilis, Staphylococcus aureus and Pasturella multocida) by Disc Diffusion method. Streptomycin was used as the positive controls, while DMSO was negative control. The activities were maximum for strain Pasturella multocida, while they were least active against Escherichia coli. Ligand $\mathrm{HL}^{3}$ was most active among against all strains of bacteria. More bulky structures results in greater lipophilicity and hence their greater diffusion through the microbial cell membrane thus ultimately causing the greater sensitivity of the 
microbes. The difference in the efficiency of various bioactive compounds towards organisms relies upon their permeability through cell membrane [15].

Table 2 Comparison of antibacterial activities of ligands $\mathrm{HL}^{2}-\mathrm{HL}^{4}$

\begin{tabular}{|l|l|l|l|l|}
\hline \multirow{2}{*}{ Compounds } & \multicolumn{4}{|l|}{ Average zone of inhibition (mm) } \\
\cline { 2 - 5 } & E. coli & B. subtilis & S. aureus & P. multocida \\
\hline Streptomycin & $30^{\mathrm{a}} \pm 0.26$ & $30^{\mathrm{a}} \pm 0.19$ & $30^{\mathrm{a}} \pm 0.23$ & $30^{\mathrm{a}} \pm 0.29$ \\
\hline $\mathbf{H L}^{\mathbf{2}}$ & $20^{\mathrm{bc}} \pm 0.14$ & $19^{\mathrm{bc}} \pm 0.13$ & $18^{\mathrm{c}} \pm 0.13$ & $21^{\mathrm{bc}} \pm 0.16$ \\
\hline $\mathbf{H L}^{\mathbf{3}}$ & $20^{\mathrm{bc}} \pm 0.13$ & $20^{\mathrm{bc}} \pm 0.11$ & $19^{\mathrm{bc}} \pm 0.15$ & $21^{\mathrm{bc}} \pm 0.12$ \\
\hline $\mathbf{H L}^{\mathbf{4}}$ & $17^{\mathrm{c}} \pm 0.14$ & $18^{\mathrm{c}} \pm 0.15$ & $19^{\mathrm{bc}} \pm 0.15$ & $20^{\mathrm{bc}} \pm 0.15$ \\
\hline
\end{tabular}

Antibacterial values are mean \pm S.D of samples analyzed individually in triplicate at $p<0.1$; Different letters in superscripts indicate significant differences. $\mathrm{a}=$ maximum activity, $\mathrm{b}=$ intermediate activity, $\mathrm{c}=$ minimum activity, $\mathrm{ab}=$ activity between maximum and intermediate and $\mathrm{bc}=$ activity between intermediate and minimum.

The maximum antifungal action, from all the studied ligands was observed by $\mathrm{HL}^{3}$. This might be due to more electronegative nature of the chloro group attached to the benzene ring. Also its insulin mimetic properties can be further explored. These complexes are potent drug candidates for further research.

Table 3 Comparison of antifungal activities of ligands $\mathrm{HL}^{2}-\mathrm{HL}^{4}$

\begin{tabular}{|l|l|l|l|l|}
\hline \multirow{2}{*}{ Compounds } & \multicolumn{4}{|l|}{ Average zone of inhibition (mm) } \\
\cline { 2 - 5 } & A. alternata & G. lucidum & A. niger & P. notatum \\
\hline Fluconazole & $38^{\mathrm{a}} \pm 0.41$ & $41^{\mathrm{a}} \pm 0.52$ & $40^{\mathrm{a}} \pm 0.36$ & $35^{\mathrm{a}} \pm 0.27$ \\
\hline $\mathbf{H L}^{\mathbf{2}}$ & $20^{\mathrm{c}} \pm 0.12$ & $22^{\mathrm{bc}} \pm 0.15$ & $18^{\mathrm{c}} \pm 0.15$ & $20^{\mathrm{c}} \pm 0.10$ \\
\hline $\mathbf{H L}^{\mathbf{3}}$ & $22^{\mathrm{bc}} \pm 0.21$ & $25^{\mathrm{bc}} \pm 0.22$ & $22^{\mathrm{bc}} \pm 0.23$ & $26^{\mathrm{bc}} \pm 0.25$ \\
\hline $\mathbf{H L}^{4}$ & $24^{\mathrm{bc}} \pm 0.08$ & $21^{\mathrm{c}} \pm 0.34$ & $23^{\mathrm{bc}} \pm 0.28$ & $25^{\mathrm{bc}} \pm 0.16$ \\
\hline
\end{tabular}

letters in superscripts indicate significant differences. $a=$ maximum activity, $b=$ intermediate activity, $\mathrm{c}=$ minimum activity, $\mathrm{ab}=$ activity between maximum and intermediate and $\mathrm{bc}=$ activity between intermediate and minimum.

\section{Conclusion}

New azomethine bearing ligands were synthesized, while characterized by FT-IR and NMR spectroscopy. FT-IR confirmed the synthesis of ligands depicting $\mathrm{CH}=\mathrm{N}$ peaks; which are characteristic of azomethine moiety. NMR spectra gave $\mathrm{CH}=\mathrm{N}$ signals verified the binding of precursor for ligand synthesis. All the synthesized complexes spontaneously tied with DNA, shown by negative $\Delta G$, impairing DNA structure, via UV-Visible spectroscopy; which made them potential anticancer antitumor drugs to further research work. Their moderate binding constants/affinity meant they were less toxic to normal cells in curing cancers or tumors. Besides others $\mathrm{HL}^{2}$ especially had remarkable antibacterial and antifungal activity so these synthesized complexes could be investigated for future drugs.

\section{References}

[1] K.M. Hambidge, N.F. Krebs, Zinc deficiency: a special challenge, J. Nutr., 137 (2007) 1101-05.

[2] H. Sakurai, Y. Kojima, Y. Yoshikawa, K. Kawabe, H. Yasui, Antidiabetic vanadium (IV) and zinc (II) complexes, Coord. Chem. Rev., 226 (2002) 187-198.

[3] A. Shisheva, D. Gefel, Y. Shechter, Insulinlike effects of zinc ion in vitro and in vivo: preferential effects on desensitized adipocytes and induction of normoglycemia in streptozocininduced rats, Diabetes, 41 (1992) 982-988. 
[4] H. Sakurai, A. Katoh, Y. Yoshikawa, Chemistry and biochemistry of insulin-mimetic vanadium and zinc complexes. Trial for treatment of diabetes mellitus, Bull. Chem. Soc. Jpn., 79 (2006) 16451664.

[5] M. K. Song, M.J. Rosenthal, S. Hong, D. M. Harris, I. Hwang, I. Yip, M.S. Golub, M.E. Ament, V.L.W. Go, Synergistic antidiabetic activities of zinc, cyclo (his-pro), and arachidonic acid, Metabolism, 50 (2001) 53-59.

[6] Y. Yoshikawa, Y. Adachi, H. Sakurai, A new type of orally active anti-diabetic Zn (II)dithiocarbamate complex, Life Sci., 80 (2007) 759-766.

[7] M. Sirajuddin, S. Ali, A. Badshah, Drug-DNA interactions and their study by UV-Vis., fluorescence spectroscopies and cyclic voltametry, J. Photochem. Photobiol. B: Biol. 124 (2013) 1-19.

[8] V. González-Ruiz, A. I. Olives, M. A. Martín, P. Ribelles, M. T. Ramos, J. C. Menéndez, An overview of analytical techniques employed to evidence drug-DNA interactions. Applications to the design of genosensors, Biomed. Eng. Trend. Res. Technol., 32 (2011) 65-90.

[9] W.L.F. Armarego, C.L.L. Chai, Purification of laboratory chemicals, (2013), 7th Ed; Elsevier (USA).

[10] S. Dey, S. Sarkar, H. Paul, E. Zangrando, P. Chattopadhyay, Copper (II) complex with tridentate $\mathrm{N}$ donor ligand: Synthesis, crystal structure, reactivity and DNA binding study, Polyhedron 29 (2010) 1583-1587.

[11] S. Shujha, A. Shah, N. Muhammad, S. Ali, R. Qureshi, N. Khalid, A. Meetsma, Diorganotin (IV) derivatives of ONO tridentate Schiff base: Synthesis, crystal structure, in vitro antimicrobial, anti-leishmanial and DNA binding studies, Eur. J. Med. Chem. 45 (2010) 2902-2911.

[12] K. Rizwan, M. Zubair, N. Rasool, M. Riaz, M. Zia-Ul-Haq, V. de Feo, Phytochemical and biological studies of Agave attenuata, Int. J. Mol. Sci. 13 (2012) 6440-6451.

[13] N. R. Bhalodia, V. Shukla, Antibacterial and antifungal activities from leaf extracts of Cassia fistula 1.: An ethnomedicinal plant,J. Adv. Pharm. Technol. Res. 2 (2011) 104-109.

[14] T. Yu, W. Su, W. Li, Z. Hong, R. Hua, M. Li, B. Chu, B. Li, Z. Zhang, Z. Z. Hu, Synthesis, crystal structure and electroluminescent properties of a Schiff base zinc complex, Inorg. Chim. Acta 359 (2006) 2246-2251.

[15] C.D. Sheela, C. Anitha, P. Tharmaraj, D. Kodimunthri, Synthesis, spectral characterization, and antimicrobial studies of metal complexes of the Schiff base derived from [4-amino-Nguanylbenzene sulfonamide] and salicylaldehyde, J. Coord. Chem., 63 (2010) 884-893. 